Piśmiennictwo zakonne $w$ dobie staropolskiej, red. Magdalena Kuran, Katarzyna KaczorScheitler i Michał Kuran, przy współpracy Dawida Szymczaka, Łódź 2013.

BEATA ŁUKARSKA ${ }^{1}$

Akademia im. Jana Długosza w Częstochowie

\title{
Formacja życia duchowego w wybranych medytacjach zakonnych z XVII i XVIII wieku
}

Proszę, dla miłości Boskiej, aby mi tych książek nie brać, bo by mi wielką ciężkość uczynił².

Ta nota wpisana w rękopiśmienny zbiór tekstów medytacyjnych, prawdopodobnie ręką poniżej podpisanej Agnieszki Józefy Jarzyńskiej — zakonnicy św. Benedykta, świadczyć może o wartości literackich przekazów dla życia religijnego ówczesnych wspólnot zakonnych. Jednak nie tylko wspólnoty zakonne tworzyły te tak specyficzne dokumenty kultury i duchowości, i nie tylko one były indywidualnymi bądź zbiorowymi ich odbiorcami. Pełna różnorodność zapisków ujawnia się choćby w szczegółowych autorskich wskazaniach, tworząc swoistą systematykę przeznaczenia.

Mamy zatem kodeksy drukowanych bądź rękopiśmiennych rozważań sporządzonych dla: środowisk mniszych, bez konkretyzacji, czy chodzi o duchowość wspólnot żeńskich, czy męskich, czego przykładem: Adriana Kozłowicza, Klejnot dusz chrześijańskich, zwłaszcza poświęconych Bogu (Warszawa 1688); anonimowe: Wizerunk żywota zakonnego na dwie części rozdzielony... (Kraków 1613), Ogród wrotami zakonnej osobności zamknięty (rkps z 1742 roku); zabytki ze wskazaniem na środowisko panien zakonnych: Modlitwy nabożne albo medytacyje do używania ww. w Chrystusie Pannom zakonnym (rkps datowany na rok 1689), Adama Opatowiusza, Fascykut nabożeństwa różnego Panien Zakonu św. Klary (Kraków 1633); Jana Baćko, Zwierciadto dla panien zakonnych (rkps z 1608 roku). Zachowały się również teksty ukierunkowane na ściśle określone okoliczności życia klasztornego, na przykład: dorocznych

\footnotetext{
${ }^{1}$ Beata Łukarska, pracownik Akademii im. Jana Długosza w Częstochowie; historyk literatury, teolog. Stałym tematem naukowych zainteresowań jest: historia duchowości wyrażona w przekazie piśmiennictwa XVII i XVIII wieku. Wybrane publikacje: Symbolika maryjna w wybranych tekstach polskiego średniowiecza i baroku, „Świat i Słowo” 2010, nr 2; Kult cudownych wizerunków maryjnych na dawnych Kresach Wschodnich w świetle wybranych utworów literatury polskiej XVII i XVIII wieku, [w:] Dziedzictwo kulturowe regionu pogranicza, t. 4, Gorzów Wielkopolski 2011; Między liryzmem a naturalizmem $w$ tekstach pasyjnych polskiego baroku, [w:] Proza staropolska, Łódź 2011; Sposoby wartościowania czynów dobrych $i$ złych w wybranych tekstach moralistyki polskiej XVII i XVIII wieku, [w:] Zjawisko nobilitacji i deprecjacji języku. Komunikacja, Częstochowa 2012.

${ }^{2}$ Wpis na karcie tytułowej rękopiśmiennego zabytku: Modlitwy nabożne albo medytacyje z różnych autorów zebrane, 1689, sygn. B.O. 2911/I.
} 
rekolekcji — Przewodnik Bogomyślności w drodze rekolekcyi zakonnych, (rkps z 1742 roku), rozmyślania na potrzeby formacji nowicjuszek: Gabriela Kiełczewskiego, Sposób życia panien do zakonu się mających... (Kalisz 1613), Bonawentury od św. Stanisława, Dyskurs krótki... dla dusz poczynajacych ćwiczenie w modlitwie wnętrznej (rkps z XVII wieku), albo przeciwnie dla oziębłych na drodze kształtowania religijnego, czyli „spustoszonych wewnętrznie”: Positek dla ostabiałej $w$ doskonatości duszy zgotowany... (rkps datowany na rok 1742$)^{3}$, a także na zakonne jubileusze, czyli rocznice wieczystych profesji: rękopiśmienna Ksią̇ka ćwiczenia duchownego do nabożeństwa (rkps z XVIII wieku).

Część spośród owych spisanych, a później już oficjalnie drukowanych modlitewników trafiła do szerokiego odbioru czytelniczego. I tak, kobietom żyjącym poza murami kościelnymi, czyli w tak zwanym świecie ${ }^{4}$, służyć miał anonimowy cykl siedemnastowiecznych maryjnych rozważań - Bogomyślna z Panem Bogiem rozmowa, to jest modlitwy ku nabożenstwu białej ptci stużące (rkps XVII/XVIII wieku); starym i chorym ${ }^{5}$ zakonni pisarze proponowali teksty w rodzaju pracy Marcina Bogumiła Grzymosza Wesote dobrej śmierci czekanie (Kraków 1687), bądź Józefa Dambrowskiego - Wyprawa duchowna $w$ drogę szczęśliwej wieczności ${ }^{6}$ (Częstochowa 1762).

Osobną grupę stanowiły wszelkiego zamysłu oraz kompozycji „rozmyślania”, „rozważania”, „uważania”, samodzielne lub fragmentaryczne (te ostatnie wplecione w zespół modlitw o innym charakterze), a wyrosłe z duchowości pasyjnej, dokładniej jako rezultat duszpasterskiego oddziaływania popularnych już od siedemnastego stulecia polskich Kalwarii. Ich przykładem: Mariana Postękalskiego - Dróg odkupienia naszego [...] na gruncie Zebrzydowskim nowa pamiątka (Kraków 1611), bernardyński, anonimowy traktat Prowiant duchowny na drogi święte kalwaryjskie pielgrzymujacym (Kraków 1661), oraz Drogi cierniowe albo modlitwy serdeczne rozdzielone na tajemnice Męki Pana (Kraków 1655)7.

\footnotetext{
${ }^{3}$ Podobne przeznaczenie jest wpisane w zbiór tekstów o oryginalnej kompozycyjnie (listy mistyczne) formule: Zwierciadto żywota duchownego, rkps B.O. 1203/I.

${ }^{4} \mathrm{O}$ zamierzonej, szerokiej orientacji czytelniczej, trochę zapewne żartobliwie, informuje autor propagujący tzw. pobożność afektywną: „, [...] tu i baba szpitalna może się starać [...] ta droga [...] nie potrzebuje bowiem bystrości dowcipu albo subtelności rozumu naszego, wszystko albowiem to jakieś skupienie w afekcie się bawi i odprawuje". Zob. Nauka o obecności Bożej przez afekt.., rkps B.O.1270/I.

${ }^{5}$ Takie też przeznaczenie wpisane zostało w zbiór pasyjnych rozmyślań przeplecionych krótkimi lub dłuższymi modlitwami oraz egzemplami autorstwa Jana Andrzeykiewicza. W słowach następujących potwierdza to także sam autor: „Patrz delikacie na to łoże Jezusowe, a gdyć chyragra ręce, podagra nogi łamie; gdy na miękko usłanym łożu choroba uleżeć ci nie dopuszcza, na to twarde łoże pamiętaj!”. Zob. J. Andrzeykiewicz, Ziarno gorczyczne gorzkiej męki Najstodszego Zbawiciela..., Wilno 1673, s. 145.

${ }^{6} \mathrm{~W}$ części trzeciej swego dziełka adres wydawniczy tak precyzuje sam autor: „tak kapłanom dla dyspozycyi chorych i na śmierć skazanych, jako też samym chorym i zdrowym przez różne akty, a osobliwie przez ośmiodniową rekolekcyją".

${ }^{7} \mathrm{~W}$ podtytule znajdziemy następujące zalecenie: „nie tylko ludziom pospolitym, ale kapłanom, zakonnikom, którzy modlitwę rozmyślania czynią. Podobne przeznaczenie można wyczytać z dziełka autorstwa Józefa Porzęckiego - Positek duszny albo Rozmyślania o Męce Pańskiej na każdy dzień wielkiego Postu..., Lwów 1740.
} 
Równie zróżnicowane było środowiskowe pochodzenie medytacyjnych zbiorów. Obok szczególnie w tej materii wyróżniających się zgromadzeń karmelitańskich, benedyktyńskich (również norbertanek), dla których lektura tekstów medytacyjnych, a nawet twórczość tego rodzaju własna bądź naśladowcza, były tradycyjnymi elementami dyscypliny zakonnej oraz warunkowały przyjęcie do zakonu. Wymienić jeszcze trzeba znaczących dla produkcji literackiej w siedemnastym stuleciu jezuitów: Kaspra Drużbickiego, Jana Morawskiego, Jana Witkowskiego, Tomasza Młodzianowskiego; franciszkanów: Józefa Dambrowskiego, Adriana Kozłowicza oraz franciszkanów obserwy ścisłej, czyli bernardynów: na przykład przywoływane już postaci związane z Kalwarią Zebrzydowską, jak: Aleksy Piotrkowczyk czy też Marian Postękalski.

Ciekawie kształtuje się też katalog osób stanowiących wzór albo, bardziej w znaczeniu duchowym, a nie literackim, źródło zapisów medytacyjnych stworzonych przez zakonnych polskich autorów. Do kategorii pierwszej (oczywiście w znaczeniu częstotliwości przywołań) należy z całą pewnością, wymieniony w nocie tytułowej — Ambony Ducha Świętego — pióra jezuity Jana Morawskiego, założyciel Societatis Iesu — św. Ignacy Loyola?.

W drugiej wskazać można, poza źródłami patrystycznymi, z doby średniowiecza: XIV-wiecznego wyraziciela duchowości z kręgu devotio moderna - Tomasza a Kempis $^{10}$, czternastowieczną dominikańską tercjarkę św. Katarzynę ze Sieny, franciszkańskiego kardynała, św. Bonawenturę ${ }^{11}$ i niezwykle często goszczącą w tradycjach rozmyślań pasyjnych św. Brygidę Szwedzką, w zakresie licznych cytacji z jej Revelationes $(\text { Objawień })^{12}$. Bliższą tradycję budują natomiast przez różnych twórców wzorczo

\footnotetext{
${ }^{8}$ Tak o tym autor: „Czytać dobrze po polsku i po łacinie. Pisać, śpiewać [...], jeśliby się która przez pół roka tak wiele nauczyć nie mogła, a przyczyna słuszna tego wyciągać nie będzie, aby ją przyjęto, dać jej jeszcze kwartał do nauki, a jeśli jest nadzieja, że się nauczy, dać jej drugi kwartał: a gdzieżby się z tych rzeczy żadnej i przez rok nie nauczyła, to samo jej przeszkodą być musi do zakonu”. Albo w innym miejscu tekstu: „Ma być biegła i świadoma w czytaniu książek duchownych, aby przeszkody w życiu duchownym i w pojmowaniu ćwiczenia zakonnego zdrady i szatańskie nie tylko z doświadczenia, ale też z częstego i pilnego czytania ostrożnie zrozumiała”. Zob. Gabriel Kiełczewski, Sposób życia panien do zakonu się mających wedtug reguty Augustyna świętego [...], Kalisz 1613, s. 6, 9.

${ }^{9}$ Zob. J. Morawski, Ambona Ducha Świętego albo ćwiczenia duchowne przez dziesięć dni na wzór tych, które podaje św. Ignacy..., Poznań 1700.

Założyciela Towarzystwa Jezusowego i jego Exercicia (Ćwiczenia) przywołują także: Cyryl Zuchowski, Marcin Bogumił Grzymosz, oraz rękopiśmienne anonimowe rozmyślania: Przewodnik Bogomyślności w drodze rekolekcyi zakonnych...1742 i Pobożna z Chrystusem dusze każdej chrześsijańskiej zabawa..., 1616.

${ }^{10} \mathrm{M}$. B. Grzymosz informuje o źródłach napisanych przez siebie tekstów w jawnych wskazaniach lektur poprzedzających medytacje, np. „Czytać dziś Tomasza a Kempis...” albo „Przeczytasz sobie dziś przygotowanie do kolekcji z księdza Ludwika de Ponte”. Zob. M. B. Grzymosz, Szczere samego Pana Boga w świętej pustyni szukanie albo kilkoro kolekcyi na dziesięć dni rozporządzonych [...], Kalisz 1688, nlb.

Znanym traktatem Tomasza z Kempen, O naśladowaniu Chrystusa inspirowany jest także zbiór o tytule Młotek duchowny, autora kryjącego się pod pseudonimem: Pleban Witowski. Druk z XVII wieku, w zbiorach Ossolineum znaczony sygnaturą B.O. XVII-4498 oraz nieznana z imienia zakonnica, wpisująca plan dnia w siedemnastowieczny rękopis: Sposób wzywania pomocy od Pana Boga, sygn. B.O. 2907/I.

${ }^{11}$ Ujawniona inspiracja medytacji kryjących się pod sygnaturą B.O. 3325/I.

${ }^{12} \mathrm{~W}$ tekstach rozważań Część synogarlice stużaca do rozmyślania na post o Męce Pańskiej, rkps B.O. 2910/I.
} 
przywoływani albo na użytek praktyki rodzimego czytelnika tłumaczeni: Ludwik del Ponte $^{13}$, Jakub di Stella, Hieronim Drexeliusz, Angela z Fulgino, Maria z Agredy ${ }^{14}$.

Godzi się jeszcze, choćby w wymiarze jednego zdania, podjąć kwestię zróżnicowania treściowego. W tym zakresie wyróżnić trzeba: teksty medytacyjne o treści biblij$n e j^{15}$, (w tym często rozważania starotestamentowych psalmów $\left.{ }^{16}\right)$, eucharystycznej ${ }^{17}$, chrystologicznej, na przykład powiązane z rodzącym się kultem Serca Jezusowego (Objawienia św. Małgorzaty Marii Alacoque) w wymiarze polskim propagowanym przez jezuickiego teologa Kaspra Drużbickiego ${ }^{18}$, maryjnej (kształtująca się prawda Niepokalanego Poczęcia NMP, motyw naśladowania NMP ${ }^{19}$, modlitewne ${ }^{20}$ oraz oparte na fundamencie życia wspólnotowego ${ }^{21}$, na przykład na przyjętej zakonnej regule ${ }^{22}$.

\section{KOMPOZYCJA, FORMA, PORZĄDEK ROZMYŚLAŃ, SZCZEGÓŁOWE WARUNKI ZEWNĘTRZNE}

Czas modlitewnego skupienia nad tekstami służącymi późniejszej osobistej medytacji był ściśle określony i opisany szczegółowym porządkiem zakonnego dnia. Poznać go możemy, między innymi, dzięki zachowanym rękopiśmiennym „okładkowym” dopiskom nieznanej z imienia benedyktyńskiej zakonnicy:

Rozporządzenie czasu na kolekcyjach. Naprzód Jutrznia, w pół nocy; od pierwszej do drugiéj — medytacyja, po niej refleksyja, czytać książkę Tomasza de Campus, to jest Naśladownik i dyscyplinę odprawiać, iść spać.

Od piątej do szóstej ranny pacierz, iść na punkta, od szóstej do siódmej słuchanie mszej ś‘więtej, modlitwy ranne.

\footnotetext{
${ }^{13}$ Dowodem te słowa: „[... ] to samo, że we wszystkich językach jest co dość z łaski Bożej rozmyślania, nie tylko w samym druku, ale też i w bogomyślnym używaniu, jeśli pod niebem polskim Ludovicus de Ponte po polsku przetłumaczony, co do rozmyślania należy”. Zob. M. B. Grzymosz, Szczere samego Pana Boga szukanie...,t. 1, Kalisz 1688, nlb.

${ }^{14}$ Część synogarlice..., rkps B. O. 2910/I.

${ }^{15}$ Na przykład: Exercitia duchowne złożone od w. o. Bonawenturę od s. Stanisława...; zabytek rękopiśmienny pod sygn. B.O.1267/I.

${ }^{16}$ Rozważania wokół tzw. Psalmów ufności (PS 26, 84,124,133) znaleźć można w: M. B. Grzymosza, Wesołe dobrej śmierci czekanie..., Kraków 1687; Psalmy są również myślą przewodnią rękopiśmiennego zbioru: Sposób wzywania pomocy od Pana Boga na każdy dzień na rozmyślaniu tygodniowym, sygn. B.O. 2907 oraz M. Postękalskiego, Dróg odkupienia naszego [...] na gruncie Zebrzydowskim: Nowa pamiątka, Kraków 1611.

${ }^{17}$ Np. Sposób wzywania pomocy od Pana Boga..., gdzie znajdziemy takie słowa wprowadzające: „Naprzód, iż msza święta nic inszego nie jest tylko pilne i nabożne uważanie i powtarzanie Męki Pańskiej”, k. 92. Element eucharystyczny (rozważania na Komunię) znajdziemy także w: Książka ćwiczenia duchownego do nabożenstwa należaca, rkps B.O. 2906/I.

${ }^{18}$ Zob. K. Drużbicki, Serce Jezusowe meta albo cel serc stworzonych [...] pospolitej wszystkich mitości wystawiony, Poznań 1696.

${ }^{19}$ Na przykład: J. Witkowski, Obserwacyje święte czasu rocznego albo dni niektóre w roku honorowi Jezusa, Matki Najświętszej i świętych Pańskich poświęcone..., Poznań 1730 albo Akty nabożne do Najświętszej P‘anny) Maryjej na święto Niepokalanego Poczęcia, rkps B.O. 2909/I.

${ }^{20}$ Rozmyślania wokół Ojcze nasz w: Częś́ synogarlice..., Rkps B.O. 2910/I.

${ }^{21}$ Rozmyślania mogą towarzyszyć zwykłemu porządkowi dnia, tak jak: Rozmyślania przy stole o biesiadach Pana Jezusowych zapisane... Zob. w: Sposób wzywania..., k. 72-73.

${ }^{22}$ Rękopis o sygn. B.O. 9513/I albo w: G. Kiełczewski, Sposób życia panien..., Kalisz 1613.
} 
Od siódmej do ósmej: Pryma, Tertia, Sexta, godzinek małych mówienie. Od ósmej do dziewiątej: medytacyja druga. Od dziewiątej do dziesiątej refleksyja a medytacyja, pisanie pożytków z medytacyi, notowanie postanowienia i czytać książkę duchowną. Od dziesiątej do jedenastej nonę odprawić, regułę czytać i do obiadu benedictie zmówić. Od jedenastéj do dwunastej obiad i gracias. N‘ajświętszy〉 Sakrament nawiedzić, rachunek sumnienia odprawić. Od dwunastej do pierwszej ustny pacierz, koronkę, różaniec zmówić. Od pierwszej do drugiej: refleksyja, punkta na medytacyją.

Od drugiéj do trzeciéj medytacyja trzecia.

Od trzeciéj do czwartéj nieszpór, refleksyja na medytacyją, czytać książkę duchowną, akty, postanowienia sobie poprzeczytawać i notować. [...]. Od piątej do szóstej punkta na medytacyją północną [...]. Od szóstej do siódmej w celi nabożeństwo, umartwienie jakie, przypomnienie sobie medytacyi, aktów i postanowienia ${ }^{23}$.

Cytowana uprzednio autorka zapisków wskazuje na trzykrotną lekturę tekstów przygotowujących ją i zapewne jej towarzyszki do nabożnego skupienia. Nie była to jednak praktyka ściśle ustalona, skoro brat Eliasz z zakonu Swiętej Trójce od Wykupu Niewolników zaleca odbiorcom swego dziełka dwukrotne medytacje, czyli poranne i poobiednie $e^{24}$. Zdaniem jeszcze innych pisarzy ascetycznych takie nabożne praktyki usystematyzować należy w jednej konkretnej części dnia: tylko rano ${ }^{25}$ lub tylko wieczorem $^{26}$. Pominąwszy liczbę przyjętych i praktykowanych nabożnych skupień, spróbujmy prześledzić miejsce tekstów wprowadzających w całym porządku modlitwy myślnej. Informację taką podaje pewna karmelitańska mniszka, twórczyni not kryjących się pod tytułem: O obecności Bożej przez afekt. Według siedemnastowiecznej karmelitanki, pierwszym punktem modlitwy są "modlitwy krótkie postrzelające, jako strzały jakie zapalone do zranienia Boga”; dalej, „uważanie” (a więc tekst będący podstawą medytacji), sama medytacja, po niej (zapewne w miarę duchowych i umysłowych możliwości modlącego się) kontemplacja i sumujące wszystko zjednoczenie, objawiające się przede wszystkim w „umartwieniu pasyi i posłuszeństwie”27. Tak mógł wyglądać, oczywiście, wybrany rozkład praktyki zakonnej.

Kolejne szczegółowe informacje, na przykład ukryte pod autorską kwestią: „Co czynić przed medytacyją" - podaje jezuita - J. Morawski. Na zadane wcześniej pytanie pisarz odpowiada w sposób następujący: „Przed spaniem, poprzedniego dnia, czytać punkta. Po obudzeniu się zaraz o tym myśleć, dalej wyobrażać siebie w danej roli, na przykład cierpiącego Chrystusa"28.

Zalecany sposób wykorzystania kolejnych części modlitewnego porządku zanotował także znany pisarz ascetyczny, dominikanin Mikołaj z Mościsk:

\footnotetext{
${ }^{23}$ Zob. Sposób wzywania pomocy od Pana Boga..., rkps B.O. 2907/I.

${ }^{24} \mathrm{~W}$ innym zaś miejscu zakonnik stwierdza nawet: „Myśl zawsze w dzień i w nocy [...] i dodaje: Myśląc albowiem o niebie jest odstąpić od świata a złączyć się z Bogiem”. Zob. Eliasz od świętego Józefa zakonu Trójcy Przenaświętszej od Wykupienia Niewolników, Zwierciadto pilnej przezorności we własnym sumieniu życia zakonnego..., Lwów 1741, s. 169.

${ }^{25}$ Zob. Rozmyślania o drogiej Męce Pana naszego Jezusa Chrystusa przez Fulviusa Androcego Societatis> Iesu złożone a przez ks. Szymona Wysockiego tegoż zakonu z wtoskiego na polskie przełożone, Kraków 1611, s. 28.

${ }^{26}$ Zob. Bogomyślna z Panem Bogiem rozmowa, to jest modlitwy ku nabożeństwu białej ptci stużące..., rkps B.O. $3650 /$ I.

${ }^{27}$ Zob. O obecności Bożej przez afekt, rkps B.O.1270/I. k. 46-60.

${ }^{28}$ Zob. J. Morawski, Ambona Ducha Świętego..., nlb.
} 
To, o czym się ma medytować rozebrać i rozdzielić na pewne punkta lub to od mistrza gotowe wziąć, lub z książek, lub też sobie z Pisma Świętego sporządzić. [...] Każdy punkt spokojnie, pilnie, nieskwapliwie roztrząsać i uważać, upatrując przyczyny, z których idzie, skutki albo pożytki, które stąd płyną, okoliczności obejrzeć miejsc, czasu, osób, sposobu, które tam się znajdować mogą29.

Dla modlących się ważne były również kwestie kompozycyjne medytacyjnych tekstów, skoro benedyktyńska zakonnica, w rękopisie o tytule Część synogarlice stużąca do rozmyślania akcentuje zachowanie porządku modlitwy. Ów porządek wprowadzany był natomiast przez charakterystyczne elementy językowe. Benedyktynka pisze: „Odprawiwszy nabożnie jednę uwagę (z których każda tak zaczyna się: »Rozmyślaj albo uważaj i weźmi przedsięć) do drugiej pójdziesz takąż gorącością i dalej “"

W tym miejscu warto jeszcze wspomnieć o szczególnych warunkach niektórych medytacji. Mamy tu na myśli pomoce duchowe bądź materialne. Do pierwszych z pewnością zaliczyć trzeba zalecenie „obrania sobie patronów”, na przykład w środowisku klarysek św. Kingi, czy też — jak w tytule samych rozmyślań zaznaczono — św. Kunegundy. Czytamy bowiem:

Święta Kunegunda [...] na to cię ze świata swą przyczyną do zakonu świętego wezwała, na to cię chowa, na to wielki koszt na opatrzenie twoje postanowiła, abyś wygodę mając z cnoty w cnotę postępując miłą oblubienicą Chrystusa twego była ${ }^{31}$.

W rozważaniach benedyktyńskich przywołuje się natomiast albo „ojców świętych w osobach zakonnych”, albo też, w sposób wyraźniej ukonkretniony w przypadku tekstów spisanych przez mniszki tej wspólnoty — „najświętszą matkę s. Skolastykę”32.

Nieco inaczej kształtuje się dyscyplina praktyk medytacyjnych zalecanych zakonnej młodzieży, czyli nowicjuszkom. Pieczę nad kształtowaniem osobowości przyszłych członkiń zgromadzenia powierzano mistrzyni nowicjatu. O obowiązkach tej starszej i doświadczonej mniszki czytamy między innymi: „Rozmyślania jakiekolwiek nowicjuszkom dawać będzie, sama je pierwej niech rozmyśla albo uważnie przeczyta”33. Iw drugim miejscu: „A Panna Mistrzyni przy rozdawaniu rozmyślania z reguły stanu zakonnego człowieka i własne powinności jego niechaj jako najlepiej i najwyrozumialej do ich pojęcia objaśnia” ${ }^{34}$.

Przygotowujących się do życia klasztornego zobowiązuje się jeszcze do ćwiczeń przez rozmowy duchowe: „naznaczona na rozmowę weźmie cokolwiek z rozmyślania swego [...] i tak przy rozmowie spyta drugich"; albo przez spisywanie własnych duchowych refleksyi: „[...] gdyż z pisania nowicjuszek gorącość ducha i postępek ich w ćwiczeniu zakonnym albo oziębłość snadniej mistrzyni poznać może”35.

\footnotetext{
${ }^{29}$ Zob. Mikołaj z Mościsk, Akademija pobożności nie tylko zakonnym osobom do doskonałości potrzebna..., Częstochowa 1722.

${ }^{30}$ Czesść synogarlice..., B. O. 2910/I, k. 4.

${ }^{31}$ Zob. Medytacyje albo Rozmyślania stużace ku poprawie życia, mianowicie żywotem s. Kunegundy pobudzajace, $w$ Warszawie pisane, w klasztorze ojców franciszkanów 1667, Die 10 septembra, rkps. B. O. 2901/I, k. 211.

${ }^{32}$ Rozmyślania zakonne dla ss. Benedyktynek, rkps B. O. 9513/I.

${ }^{33}$ Zob. G. Kiełczewski, Sposób życia panien.., s. 10.

${ }^{34}$ Tamże, s. 49.

${ }^{35}$ Tamże, s. 52.
} 
Ostatecznie zaleca się też łączenie wymiaru intelektualnego i duchowego modlącego się medytacjami człowieka. Stąd zapewne szczególny nacisk, zwłaszcza w rozpatrywaniu treści pasyjnych ${ }^{36}$, kładzie się na uruchomienie wyobraźni. Mówi o tym następująca uwaga jednego z rękopiśmiennych tekstów:

Rozmyślający żywą myślą duszy swojej materyje albo tajemnice każdej uwagi ma przed oczy stawiać; jakby podżegać ją, aby żywo i gorąco aprehendowała na siebie, refleksyję zaostrzała, a stąd do Boga afektami wzbijała $\operatorname{sic}^{37}$.

$\mathrm{Z}$ drugiej jednak strony nie brakuje też głosów przestrzegających przed zbytnią „wytwornością", to jest imaginacją, nie podporządkowaną ani woli, ani umysłowi.

Albowiem:

Obecność Boża lubo to przez wyobrażenie, lubo przez pojęcie, rozumem ma być bez wytworności, to jest nie mam uważać ani używać wielu imaginacyi wyrażeniem obrazów i miejsc, albo jakiego rozporządzenia aktów, albo tym podobnych inszych rzeczy, w których nauka i wymysł morduje i fatyguje głowę, i porządek pilnowania obecności Pańskiej zatępia afekt nasz $[\ldots]^{38}$.

Znany nam już z poprzednich kwestii brat Eliasz opisuje natomiast swoiste wyposażenie miejsca wspólnotowej bądź indywidualnej modlitwy myślnej: Eliasz pisze:

[...] na stole superiora trupia głowa, rózga i popiół, a to dla tego, abyśmy przy refleksyi ciała posilali oraz i duszę. Patrząc na trupią głowę, pamiętali na ostatni moment życia naszego, na rózgi, abyśmy rozmyślali srogie rany Zbawiciela ${ }^{39}$.

Umartwianie ciała, wspomniane przez nabożnego zakonnika od Wykupu Niewolników, było, biorąc pod uwagę liczbę przekazów, stałą, zamykającą częścią modlitwy myślnej. Wspomina ją, między innymi, Jan Morawski (,do tego zaprzenia należy gwałt sobie czynić albo trojakie umartwienie siebie samego" ${ }^{40}$ ), Jan Andrzeykiewicz (,przykładaj dyscypliny Jezusowe do ciała twego, przez ciała twego umartwienie i ukoranie [...]”¹) oraz nieznany z imienia autor Obyczajów chwaly godnych... („,weź ćwiczenie umartwienia powierzchowne i wnętrzne na wzór umęczonego Chrystusa”ł2 ${ }^{\prime \prime 2}$.

\section{FORMACJA ŻYCIA DUCHOWEGO W WYBRANYCH TEKSTACH MEDYTACYJNYCH}

„Jest tedy medytacyja pilne i pokorne tajemnic do wiary należących poprzez rozum szukanie i wynajdywanie, aby tym byliśmy poratowani do pragnienia dobrego a od-

\footnotetext{
${ }^{36}$ Częste są zatem uwagi w rodzaju: „Staw się w Ogrójcu getsemańskim i uważaj Chrystusa bledniejącego i smucącego się". Cyt za: J. Morawski, Prawdziwy Boga Ukrzyżowanego obraz przez nabożne o Męce Pańskiej na dni czterdzieści postu rozmyślania..., Poznań 1695, nlb.

${ }^{37}$ Część synogarlice..., rkps B.O. 2910/I, k. 5.

${ }^{38}$ Obyczaje chwaty godne, które się w siostrach naszych nowicyjuszkach karmelitankach bosych zachowują..., Warszawa 1690, s. 51.

${ }_{39}$ Zob. Eliasz od św. Józefa, Zwierciadto pilnej przezorności w własnym sumnieniu życia zakonnego..., Lwów 1741, nlb.

${ }^{40}$ J. Morawski, Ambona Ducha Świętego..., nlb.

${ }^{41} \mathrm{~J}$. Andrzeykiewicz, Ziarno gorczyczne..., s. 249.

${ }_{42}$ Obyczaje chwaty godne sposób postanowienia żywota zakonnego, rkps B. O. 1777/I, k. 65.
} 
rzucenia złego" ${ }^{33}$ - napisał w swym obszernym teoretycznym traktacie o zasadach prawdziwej pobożności Mikołaj z Mościsk. Nie jest to, jak się domyślamy, opinia jednostkowa i odosobniona. Wręcz przeciwnie, podobne zapatrywanie znajdujemy w rękopiśmiennym karmelitańskim zbiorze rozważań Zwierciadle żywota duchownego czy też w benedyktyńskich cyklach rozmyślań - Częśś synogarlice stużąca do rozmyślania na post o Męce Pańskiej albo Sposób modlitwy wnętrznej.

Ostatni z wymienionych tekstów przekonująco uściśla i praktycznie rozwija tę stosunkowo lakoniczną definicję dominikańskiego teologa. Czytamy we wspomnianym tekście słowa następujące:

[...] tak i rozmyślający nie w ten czas z pożytkiem duszy rozmyśla, gdy tylko tajemnicę medytacyi poznawa, ale gdy do swego życia stosuje; i na afekty łącząc dusze z Panem Bogiem zdobywa się, bo z takiego rozmyślania cnoty święte różne w duszy powoli rodzą się i rozkrzewiają, a najbardziej bojaźń synowska ku Panu Bogu i miłość gorąca, z których inne wypływają cnoty i duchowne postępki ${ }^{44}$.

W świetle tak sformułowanych obowiązów zakonnych tłumaczy się pierwszy z pożądanych owoców praktykowanych medytacji. W kolejnych częściach, punktach klasztornych zapisków pojawiają się zatem nawoływania, by dostosowywać własne życie do świętości zakonnych ojców i matek założycieli.

$\mathrm{Na}$ przykład, w Rozmyślaniu zakonnym dla ss. Benedyktynek, punkt 3: „Imaginuj jakoby Najświętsza matka s. Skolastyka [...] osobliwie święci zakonu twojego stawili się za tobą do Pana i przyrzykali imieniem twym nawrócenie obyczajów”45.

Albo w przekazie przeznaczonym dla zwierzynieckich klarysek, w Medytacyjach, czyli Rozmyślaniach żywotem św. Kunegundy, dokładnie w Medytacyi o marności świata, punkt 3: „Uważ, jako cię do tego pobudzić ma i do skutecznej poprawy życia intencyją koszt na cię łożony Matki twojej s. Kunegundy [... ${ }^{346}$.

Po przywołanych uprzednio wskazaniach ogólnych, w tekstach staropolskich rozważań występują często wyliczenia pożądanych cnót szczegółowych. Zażywający więc „modlitwy myślnej” mają się starać o otrzymanie tą drogą cnoty wdzięczności („na to medytacyja, abyśs uważywszy, co Chrystus [...] ucierpiał, życia swego polepszał a wdzięcznym się stawał” ${ }^{47}$ ), teologalnej cnoty cierpliwości (,że ten dług zapłacić możemy najprzód aplikując sobie cierpliwość”8) i oczywiście zakonnej pokory („,czwartej godziny upatruj przeszkody, któreś w sobie miała do pokory”99).

Wśród owoców medytacyjnego doskonalenia wymienia się także wszelkie postanowienia, na przykład takie, jak to znajdujące się we fragmencie wniosków z „ekzercycyj” w roku 1683 przez pewną karmelitankę odbywanych — lepszego niż dotąd ćwiczenia się w modlitwie „tak wnętrznej jako i ustnej”50.

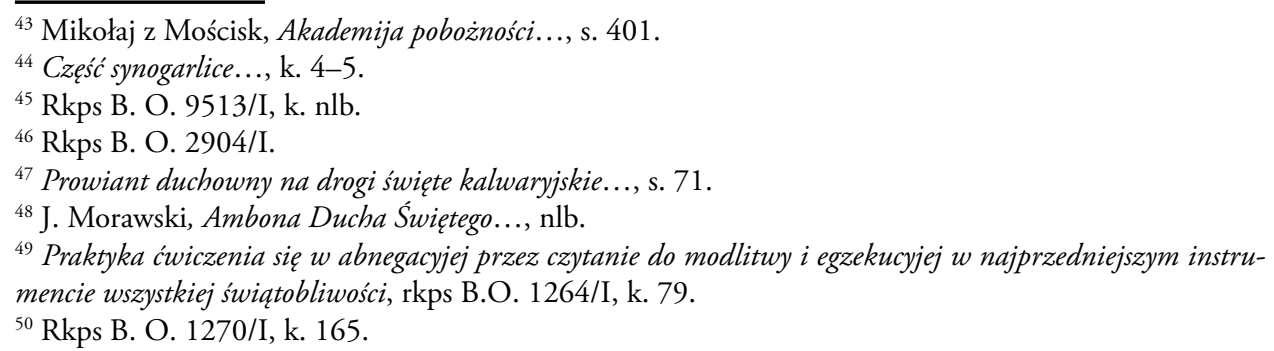


Nie zabraknie też duchowych obietnic dotyczących powszedniego życia wspólnotowego. Tak określa je benedyktyńska zakonnica rozważająca scenę fałszywego oskarżenia Chrystusa przed sądem Kajfaszowym:

Ucz się stąd nikogo nie oskarżać kłamliwie ani potwarzy zarzucać złośliwie i owszem, ani prawdziwych na bliźniego trząść defektów, bo to prawo na sercach ludzkich wyryte, co tobie nie miło, tego drugiemu nie czyń ${ }^{51}$.

Najdoskonalszym jednak stopniem pomedytacyjnej samorealizacji jest, postulowane w kontekście rozważań pasyjnych: całkowite, doskonałe zjednoczenie się, a nawet utożsamienie (echo devotio moderna i średniowiecznej idei imitatio Christi) z cierpiącym i umierającym na krzyżu Chrystusem.

Ideę tę przywołują kolejne fragmenty rękopiśmiennych rozmyślań nieznanych z imienia siedemnastowiecznych mniszek. W pierwszym czytamy:

Przy całodziennych zabawach zapatrywać się będę na Ukrzyżowanego Zbawiciela mojego, rozbirając boleści Jego, czytając jako z księgi otworzonéj nauki do świątobliwego życia $[\ldots]^{52}$.

Drugi natomiast ma charakter osobistego aktu zawierzenia, zamkniętego w kształcie osobistego wyznania:

O najukochańszy Zbawicielu! Dosyć, dosyć świętą pokazałeś mi na sobie formę; [...] od tej formy przykładu Twego odwracałam oczy, i Twoją Najświętszą nie kontentowałam się dyspozycyją ${ }^{53}$.

Trzeci i ostatni, ciekawszy od poprzednich pod względem formy artystycznej, bo przybierający kształt metafory lustrzanego odbicia:

Postaw dwa obrazy przed sobą: jeden obraz duszej swojej; drugi obraz Chrystusa Pana i dobrodzieja twego. Obraz dusze twojej na rozumie ślepy [...] Chrystus światłość mądrości niebieskiej ofiarujęć się być i drogą, i prawdą do wiecznego żywota ${ }^{54}$.

Pochodną zmetodyzowanego kształtowania siebie ad instar Christi (na wzór Chrystusa) jest stale obecne w zakonnych rozmyślaniach wołanie o podporządkowanie, a właściwie oddanie własnej woli, na sposób duchowy, po pierwsze — Bogu, a na sposób zwykły, po drugie - reprezentującym Go przełożonym. Wspomina o tym na marginesie swoich rozważań, prawdopodobny, bo wpisany z imienia przez kopistkę, autor dziełka o tytule: Exercitia duchowne - o. Bonawentura, w słowach następujących:

Masz być posłuszną Bogu. Najprzód, w zachowaniu praw Jego i obserwancyjej, potym natchnienia wnętrznego. Kiedy i do czego zakołacze w serce, nie odpychać Go od siebie, ale Mu dać miejsce, i uczynić to, do czego pobudza. Masz być posłuszną i przełożonem twojem, na miejscu Boskim zostającym. Uczyńże mocne postanowienie $\mathrm{w}$ takim posłuszeństwie żyćs5.

\footnotetext{
${ }^{51}$ Rkps B. O. 2910/I

${ }_{52}$ Wzgarda próżności świata albo księga, $w$ której zamykają się traktaty rozmyślania nabożnego o mitości Boskiej [...] przez ojca Jakuba di Stella napisana [...], a potym na polski [...] przettumaczona, Kraków 1690, s. 11.

${ }^{53}$ Rkps B. O. 2910/I, k. 27.

${ }^{54}$ Exercitia duchowne o. Bonawentury. Rkps B.O. 1267/I, k. 16.

${ }^{55}$ Rkps B.O. 1267/I, k. 29.
} 
Stałe i metodyczne praktykowanie medytacji, niezależnie od ich tematu i powiązania z rokiem liturgicznym bądź tajemnicami wiary, prowadzić ma jednak (i to przede wszystkim) do doskonalenia się w powołaniu zakonnym. Stąd tak często w rozmyślaniach znaleźć można bardziej lub mniej osobiste wspomnienia, w typie:

A tu postanów sobie, którego występku, za łaską Bożą, dnia dzisiejszego masz się szczególniej strzec, i w której cnocie ćwiczyć [...]” lub „[...] ćwiczyć [...] osobliwie w cnocie, którą wzięła na miesiąc, tydzień, także też akty umartwienia tej passyi, która mię bardziej trapi ${ }^{i 6}$.

Ukoronowaniem zaś wytrwałej modlitwy myślnej, albo, jak wolą staropolscy zakonni autorzy, „bogomyślności”, powinien być, prawie zawsze czyniony, „medytacyjny" rachunek sumienia. Jego skrócony porządek w symboliczny sposób zamknie tę część rozważań:

„Sposób modlitwy wnętrznej:

I. Przypomnienie krzywdy Bogu przez grzech uczynionej (Najsłodszy Panie Jezu Chryste [...] któremum ja największą uczyniła krzywdę [...]).

II. Podziwianie nad dobrocią Boską $(\mathrm{O}$, jak wielka łaskawość twoja Panie Boże ... gdyś mię w oczach Twoich grzeszącą cierpliwie znosił [...]).

III. Oskarżenie siebie samej (Biada mnie nędznej, któram od pierwszego pojęcia rozumu mego nic dobrego nie uczyniła [...]).

IV. Podziwianie nad złością swoją [...] (O, jak wielka była złość moja, z której ja tak ciężkie i niezliczone grzechy $[\ldots]$ popełniałam $[. .]$.$) .$

V. Zawstydzenie ([...] wstydam się tak wielkiej niegodności mojej [...]).

VI. Strofowanie samej siebie ([...] dlatego słusznym prawem siebie same w oczach Twoich powinnam zganić Panie Boże [...]).

VII. Narzekanie (O, jak nieszczęsna, cóż za pożytek miałam z grzechów moich [...]).

VIII. Wyrzeczenie (wyrzykam się, Panie mój najłaskawszy, wszystkich zbrodni moich [...]).

IX. Obrzydzenie (Brzydzę się bardzo grzechami memi i bardzo ich nie lubię [...]).

X. Żal za grzechy (Żałuję dla miłości Twojej, żem Cię kiedy, nieskończone dobro, obraziła [...]).

XI. Nadzieja odpuszczenia grzechów (I, lubo mię trwożą grzechy moje [...], przecie jednakże wierzę w Twoję nieskończonę dobroć [...]).

XII. Pragnienie pokuty i strzeżenie się grzechów (Już chcę prawdziwą pokutę czynić za grzechy moje $[\ldots]) " 57$.

\section{ZAKOŃCZENIE}

Cel wypowiedzi stanowiło omówienie wybranych zabytków literatury medytacyjnej z przełomu siedemnastego i osiemnastego stulecia. Prezentowane teksty są zróżnicowane zarówno formalnie, jak i tematycznie. Wyrosły one w różnych wspólnotach duchowości zakonnej i świeckiej. Na kartach omawianych zabytków znajdujemy informacje, na przykład dotyczące wykorzystanych przez zakonnych autorów źródeł, przywoływanych tradycji życia duchowego i ascetycznego. Warte uwagi są także elementy kompozycyjnye i wewnętrzne uporządkowanie wspomnianych przekazów. Cytowane fragmenty zapisków medytacyjnych pozwalają zrekonstruować obraz me-

\footnotetext{
${ }^{56}$ T. Młodzianowski, Akty nabożne z ksiag duchowych tacińskich [...], Poznań 1680, nlb.

${ }^{57}$ O obecności Bożej przez afekt, rkps B. O. 1270/I, k. 73.
} 
chanizmów duchowego i charakterologicznego kształtowania ich odbiorców. Wynika z nich, że omawiana literatura miała charakter użytkowy, bowiem kształtowała osobowość członków wspólnot duchownych według z góry zamierzonych i uprzednio przyjętych kryteriów formacyjnych. Te kryteria miały swój początek w historycznie ukształtowanych tradycjach monastycznych, uwarunkowane były przeznaczeniem zakonnicy lub zakonnika do konkretnej pracy. Nie można zapominać i o tym, że stałe praktykowanie medytacji, oprócz nieustannego samodoskonalenia, miało prowadzić, zwłaszcza jednostki wybitniejsze, do kolejnych stopni duchowej bliskości z Bogiem, aż do ostatecznego utożsamienia się włącznie.

Niezwykłą zaś, bo więcej niż materialną wartość tych dokumentów życia religijnego symbolicznie określa nota autorstwa Eufrozyny Teofili Kobylnickiej: „Komu się te książki po mojej śmierci dostaną, proszę, żeby pamiętał na duszę moję"58.

The Formation of Spiritual Life in Selected Monastic Meditations from the $17^{\text {th }}$ and $18^{\text {th }}$ centuries

\section{Summary}

The article is an analysis of the form and content of selected monastic meditations. Coverage, which has become the base for the analysis, deals with various subjects. They are to testify passion, Marian and other important events from monastic life spirituality such as renewing life according to the requirements of a monastic rule. The authors of chosen meditations represent various schools of spirituality, for example, Benedictine, Carmelite and Jesuit. The article shows the role of prayer in the formation of spiritual life of both an individual and monastic community.

\footnotetext{
${ }^{58}$ Dopisek na karcie tytułowej rękopiśmiennego zbioru o sygnaturze B. O. 2911/I.
} 